\title{
Short- and Long-Term Vegetation Change Related to Grazing Systems, Precipitation, and Mesquite Cover
}

\author{
Fadzayi E. Mashiri, ${ }^{1}$ Mitchel P. McClaran, ${ }^{2}$ and Jeffrey S. Fehmi ${ }^{3}$ \\ Authors are ${ }^{1}$ Research Assistant, ${ }^{2}$ Professor, and ${ }^{3}$ Assistant Professor, School of Natural Resources, University of Arizona, Tucson, AZ 85721 , USA.
}

\begin{abstract}
Rangeland scientists struggle with how long rangeland experiments must continue in order to detect treatment effects, particularly in semiarid ecosystems characterized by slow responses and high spatiotemporal variability. We compared changes in eight grass and three shrub categories to grazing systems (yearlong vs. seasonal rotation with equivalent long-term stocking rates), and covariates (precipitation and mesquite [Prosopis velutina] gradients) over $12 \mathrm{yr}$ (1972-1984) and $34 \mathrm{yr}$ (1972-2006) on the Santa Rita Experimental Range, Arizona. We used split-plot analysis of variance, with year as the split, to make these comparisons. Grazing systems did not influence plant dynamics as shown by the lack of grazing system by year effect on all response variables in either time period. The absence of a detectable grazing effect on vegetation changes may be due to overriding influences of grazing intensity, pasture size, precipitation variability, and few replicates. Also, more time may be needed to detect the small accumulating and potentially temporary effects from grazing systems. The grazing system main effects present at the beginning and throughout the study suggest that pastures assigned to each grazing system had different potentials to support vegetation. Nearly twice the number of response variables were related to the precipitation covariate than to mesquite cover, but only about half of all the relationships were consistent between time periods. The struggle to know how long to observe before detecting a grazing system effect was not resolved with the additional $22 \mathrm{yr}$ of observation because we cannot definitively reject that either more time is needed to detect small but cumulative effects or that the two grazing systems are not different.
\end{abstract}

\section{Resumen}

Científicos en la ciencia de manejo de pastizales tienen dificultades al determinar la extensión de los proyectos sobre manejo de pastizales de forma que se puedan determinar los efectos debido a los tratamientos, especialmente en ecosistemas de zonas áridas que se caracterizan por una respuesta demasiado lenta y una alta variabilidad a nivel de espacio y tiempo. Se comparó los cambios de ocho gramíneas y tres arbustivas entre diferentes sistemas de pastoreo (continuo Vs. rotacional estacional, con cargas animales similares a largo plazo). Se utilizó la precipitación y el Mesquite (Prosopis velutina) como covariables sobre 12 años (1972-1984) y 34 años (1972-2006), en la estación experimental de Santa Rita, en Arizona. Se usó un análisis de varianza de parcelas-dividas utilizando los años como parcelas, para llevar a cabo estas comparaciones. Los sistemas de pastoreo no afectaron la dinámica de las plantas como pudo observarse por no haber efecto de año para todas las variables de respuesta en ninguno de los dos períodos. La falta detección de los efectos del pastoreo en los cambios de la vegetación se puede haber debido a los efectos de la intensidad de pastoreo, tamaño de los potreros, variación en la precipitación y el resultado de pocas repeticiones. Además se requeriría más tiempo para detectar los pequeñas efectos acumulativos así como los efectos temporales de los sistemas de pastoreo. Los efectos principales de los sistemas de pastoreo identificados al inicio y a través del estudio, sugieren que cada uno de los potreros asignado a cada uno de los sistemas de pastoreo tenía un potencial diferente para mantener vegetación. Cerca del doble del número de variables de respuesta estuvieron relacionadas con las covariable de precipitación que con la cobertura del mezquite, pero solamente la mitad de la relación fue consistente entre los periodos del tiempo. La dificultad para saber que tanto tiempo hay que observar antes de poder detectar el efecto de un sistema de pastoreo no se pudo resolver con los 22 años adicionales debido a que no se pudo definitivamente rechazar que ya sea que más tiempo se requiera para detectar los pequeños efectos acumulativos o que los dos sistemas de pastoreo no son diferentes.

Key Words: long-term experimentation, plant cover and density, Santa Rita Experimental Range, seasonal rotation grazing, semiarid grassland, yearlong grazing

\section{INTRODUCTION}

Detecting vegetation changes that result from different management of rangeland systems is at the core of rangeland

Research was funded in part by USDA Forest Service Rocky Mountain Research Station and Arizona Agricultural Experiment Station.

Correspondence: Mitchel P. McClaran, 325 Biosciences East, School of Natural Resources, University of Arizona, Tucson, AZ 85719, USA. Email: mcclaran@email.arizona.edu

Manuscript received 2 October 2007; manuscript accepted 21 April 2008. science. Yet for management effects to be detected, they must meet two criteria: the effects must be larger than the variability in the system, and they must reach this size during the period of observation. Therefore, one fundamental question is how long rangeland experiments must last to detect real effects, particularly in arid and semiarid ecosystems characterized by high temporal and spatial variability, slow response to management practices, and threshold-type changes in vegetation that may limit response to some management practices (e.g., Westoby 1980; Ellis and Swift 1988; Milchunas et al. 
Table 1. Pasture size, elevation range, proportion of sandy loam upland (SLU) and sandy loam deep (SLD) ecological sites, stocking rate in ha - animal unit $\mathrm{yr}^{-1}$ (AUY; $\left.\bar{x}, \mathrm{SE}\right)$, annual precipitation $(\bar{x}, \mathrm{SE})$ and mesquite cover $(\bar{x}, \mathrm{SE})$ in the seven study pastures over the 12-yr (short) and 34$\mathrm{yr}$ (long) time periods in relation to grazing systems treatment (yearlong and seasonal rotation).

\begin{tabular}{|c|c|c|c|c|c|c|c|c|c|c|}
\hline \multirow[b]{2}{*}{ Pasture } & \multirow[b]{2}{*}{ Pasture size (ha) } & \multirow[b]{2}{*}{ Elevation (m) } & \multicolumn{2}{|c|}{$\begin{array}{c}\text { Ecological site } \\
(\%)\end{array}$} & \multicolumn{2}{|c|}{ Stocking rate (ha $\cdot \mathrm{AUY}^{-1}$ ) } & \multicolumn{2}{|c|}{ Precipitation (mm) } & \multicolumn{2}{|c|}{$\begin{array}{l}\text { Mesquite cover } \\
(\%)\end{array}$} \\
\hline & & & SLU & SLD & $12 \mathrm{yr}$ & $34 \mathrm{yr}$ & $12 \mathrm{yr}$ & $34 \mathrm{yr}$ & $12 \mathrm{yr}$ & $34 \mathrm{yr}$ \\
\hline \multicolumn{11}{|c|}{ Yearlong grazing } \\
\hline $2 \mathrm{~N}$ & 1801 & $1065-1185$ & 50 & 40 & $34.0(0.0)$ & $33.8(1.6)$ & $435(65.2)$ & $399(40.2)$ & $10(2.6)$ & $15(2.0)$ \\
\hline 8 & 403 & $1165-1298$ & 20 & 10 & $19.2(0.0)$ & $17.8(0.7)$ & $474(61.8)$ & $437(41.1)$ & $10(1.2)$ & $13(0.9)$ \\
\hline \multicolumn{11}{|c|}{ Seasonal rotation grazing } \\
\hline $2 S$ & 1438 & $1054-1196$ & 25 & 38 & $28.6(4.4)$ & $28.2(2.4)$ & $434(62.4)$ & $403(39.6)$ & $14(2.6)$ & $15(1.9)$ \\
\hline 3 & 1728 & $956-1033$ & 20 & 40 & $55.1(0.6)$ & $60.3(5.3)$ & $360(53.1)$ & $339(32.7)$ & $8(1.6)$ & $9(0.9)$ \\
\hline $5 S$ & 1637 & $933-1008$ & 25 & 25 & $57.5(5.8)$ & $77.5(11.2)$ & $339(45.8)$ & $326(29.7)$ & $2(0.7)$ & $4(0.5)$ \\
\hline $6 \mathrm{~A}$ & 1425 & $1178-1267$ & 20 & 80 & $28.3(4.4)$ & $35.1(3.1)$ & $425(54.9)$ & $394(37.0)$ & $11(2.2)$ & $13(1.4)$ \\
\hline $6 B$ & 1524 & $1017-1094$ & 40 & 60 & $26.6(1.4)$ & $24.4(1.6)$ & $348(46.3)$ & 330 (29.5) & $5(1.0)$ & $7(1.0)$ \\
\hline
\end{tabular}

1994; Milchunas and Lauenroth 1995: Havstad et al. 1999). This is an especially pressing issue for studies evaluating seasonal rotation grazing of livestock (Heady 1961; Briske et al. 2008).

Presumably, real treatment effects become apparent over time, even if the incremental year-to-year difference remains small or variable, because the low detection power is compensated for by allowing the effects to accumulate (and thus increase in size) over many years. For example, on semiarid rangelands many decades of observation were needed before some livestock grazing treatment effects were revealed (Gibbens et al. 1993; O'Connor and Roux 1995; Valone et al. 2002) whereas studies with $<13 \mathrm{yr}$ of observation found no treatment effects (Martin and Severson 1988; Taylor et al. 1993; Ward et al. 2004).

Livestock grazing systems that employ alternate periods of use, deferment, and rest, without reducing long-term stocking rates, are thought to improve vegetation compared to yearlong grazing by creating a uniform spatial distribution of forage use and periodically removing grazing during critical periods of plant growth (Heady 1961). Rotating high stocking density is thought to create a more uniform defoliation across plant species, thereby decreasing the competitive advantage of less preferred plant species (Kirkman and Moore 1995; Teague and Dowhower 2003), and periodic growing seasons without grazing are thought to allow recovery and recruitment of plants (Teague et al. 2004). However, any effects of seasonal rotation may be complicated by the interaction among grazing intensity, plant phenology, along with the length and quality of the growing season (Olson and Richards 1988; Briske 1991; Mathew et al. 2000; Briske et al. 2008).

Interpretations of the lack of grazing effects in arid and semiarid systems often invoke post hoc influences of precipitation variability and neighboring nonforage species (Ellis and Swift 1988; Milchunas et al. 1994; Fynn and O'Connor 2000; Khumalo et al. 2007). Therefore, analytical approaches that directly account for these influences have the potential to improve the detection of grazing effects. For example, interannual and interdecadal variability in precipitation that commonly increases or mitigates plant responses to different grazing systems (Westoby 1980; Hoffman et al. 1990; Palmer et al. 1990; Ellis 1994; Fynn and O'Connor 2000; Fuhlendorf et al. 2001) can be formally accounted for with a precipitation covariate in the statistical analysis. Similarly, the influence of shrubs on herbaceous species, especially when shrub abundance does not respond to grazing management (Livingston et al. 1997; Scholes and Archer 1997; Tiedemann and Klemmedson 2004), can be accounted for with a shrub cover covariate. Furthermore, covariates are attractive compared to blocks or categories because they give a continuous representation of environmental variables and require only a single degree of freedom in the analytical model.

We applied this analytical approach to compare the vegetation changes under yearlong and seasonal rotation grazing systems that have been in place for $34 \mathrm{yr}$. A previous analysis of the first $12 \mathrm{yr}$ of the experiment (Martin and Severson 1988) found no differences in vegetation due to the grazing systems but used blocks to represent the precipitation gradient and did not account for shrub abundance as an explanatory variable. We expect the detection of differences in vegetation between the grazing systems will be more likely after $34 \mathrm{yr}$ than $12 \mathrm{yr}$, and the use of covariates should improve the potential to detect those effects.

\section{MATERIALS AND METHODS}

\section{Study Area}

The study was conducted on the 21500 ha Santa Rita Experimental Range $40 \mathrm{~km}$ south of Tucson, Arizona (McClaran 2003). Elevation increases from 880 to $1400 \mathrm{~m}$; major landforms are fan terraces, flood plains, basin floors, and hills and mountains; and soils are in the thermic temperature regime and Typic Aridic, Ustic Aridic, and Aridic Ustic soil moisture regimes (Breckenfield and Robinett 2003). The major ecological sites are sandy loam deep and sandy loam upland (Table 1; US Department of Agriculture, Natural Resources Conservation Service [USDA, NRCS] 2003). A 270-440 mm gradient of mean annual precipitation largely follows the elevation gradient (McClaran 2003; Table 1). Precipitation is characterized by high interannual variability of winter (October-May) and summer (June-September) precipitation with $45 \%$ and $31 \%$ coefficient of variation, respectively (Fig. 1; McClaran 2003). 


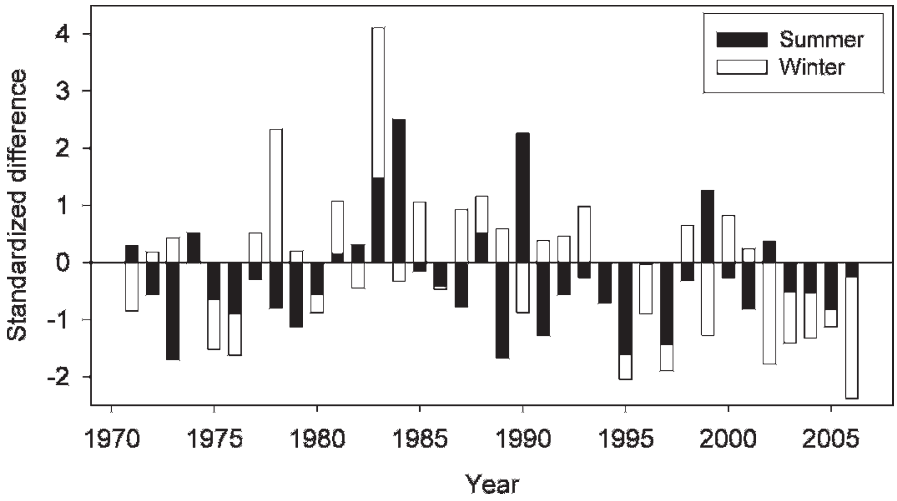

Figure 1. Standardized difference for seasonal precipitation on the seven study pastures on Santa Rita Experimental Range, 1972-1973 to 2005-2006. Precipitation year is October to September, summer months are June through September. Standardized difference is the individual year value minus long-term (1922-2006) average (winter mean $=158 \mathrm{~mm}$, summer mean $=213 \mathrm{~mm}$ ) divided by the standard deviation (winter $S D=61.0$, summer $S D=64.2$ ).

Vegetation is a mixture of shrubs, cacti, forbs, and $\mathrm{C}_{4}$ grasses (McClaran 2003). The common native perennial grasses are Arizona cottontop (Digitaria californica [Benth.] Chase), Rothrock grama (Bouteloua rothrockii Vasey), and threeawns (Aristida spp.) comprised of A. glabrata (Vasey) Hitchc., A. hamulosa Henr., and A. fendleriana Steud. Lehmann lovegrass (Eragrostis lehmanniana Nees) is the major nonnative perennial grass species introduced from the 1930s to the 1970s. The most common shrub species is velvet mesquite (Prosopis velutina Woot.), and half shrub burroweed (Isocoma tenuisecta Greene). Cane cholla (Opuntia spinisior [Engelm] Toumey), chainfruit cholla (Opuntia fulgida Engelm.), and Engelmann prickly pear (Opuntia engelmanii Salm-Dyck) are the common cactus species.

\section{Grazing Systems}

Only 7 of the 12 original pastures used by Martin and Severson (1988) could be analyzed because the seasonal rotation (SR) and yearlong (YL) grazing systems did not continue in the other pastures after 1985 (Table 1). Pastures receiving the SR treatment were grazed twice by a cow-calf herd (MarchOctober and November-February) during a 3-yr grazing cycle with 12-mo rest between each use. Average stocking rates (ha $\cdot$ animal unit year $[\mathrm{AUY}]^{-1}$ ) were calculated over the 12 and 34-yr periods, and for SR pastures these were based on 3-yr values that encompassed the entire rotation because short-term stocking rates were 3.0 times greater during the 4 - and 8 -mo grazing periods. Stocking rate variability was greater in the long term because there was inconsistent stocking immediately following the short-term period (1984-1987), but rates then stabilized to minor adjustments during dry conditions to prevent utilization $>50 \%$ (Table 1$)$. Stocking rates were slightly less (more ha $\cdot \mathrm{AUY}^{-1}$ ) than the average for the region. Average utilization between 1972 and 1984 was 50\% (Martin and Severson 1988) but was not measured from 1984 through 2006. Average precipitation (mean of two closest rain gages) and mesquite cover were based on measures from each of the permanent transects in each pasture.

\section{Vegetation Variables}

Vegetation response variables were measured on 10 permanent transects per pasture, except there were eight transects in pastures 2S and 5S (Martin and Severson 1988). Basal grass and shrub canopy cover were measured along a 30.5-m transect, and plant density was measured in a $0.305-\mathrm{m}$-wide belt along the same $30.5-\mathrm{m}$ transect (total $9.3 \mathrm{~m}^{2}$ ). Plant density was measured every 3 yr from 1972 through 1984 and 1991 though 2006; shrub canopy cover measurements followed this schedule starting in 1975; and grass basal cover measurements began in 1984 .

We lumped grasses into five categories: perennial (all perennial species), native, nonnative (E. lehmanniana and Eragrostis curvula [Shrod.] Nees), long-lived forage (D. californica, Bouteloua curtipendula [Michx.] Torr., Setaria macrostachya H.B.K., Mublenbergia porteri Scribn., and Bouteloua eriopoda Torr.; based on palatability and longevity from Ruyle and Young 1997), and threeawns (three Aristida spp. because of field identification problems). Species-level analysis of density was performed on only the most common grasses (D. californica, B. rothrockii, and E. lehmanniana) because zero values were too common for other species; and zero values for cover were very common for all grass species. Analysis of canopy cover was performed for total shrubs, $P$. velutina and I. tenuisecta; but shrub density was analyzed only for I. tenuisecta because zero values were too common for other species.

\section{Covariates}

Each pasture had separate precipitation and mesquite $(P$. velutina) cover covariates for the 12-yr short-term, 34-yr longterm, and 22-yr grass cover only observation periods (Table 1). The value for each covariate was the average of the 10 transects in the pasture over each observation period.

A separate type of precipitation covariate was used for each vegetation response variable because grasses are expected to respond most strongly to current summer and preceding winter precipitation (Cable 1975), whereas shrubs appear to respond more strongly to winter precipitation (McClaran 2003). We used six precipitation parameters: current summer (June-September) and current annual (12 mo) prior to vegetation measurements; and 2- and 3-yr cumulative summer and annual precipitation prior to vegetation measurement. The parameter with the strongest correlation between the vegetation variable over the 34-yr study period was selected as the covariate for both observation periods (Table 2). For these correlations the sample unit was the pasture (average of 10 permanent transects), and precipitation for each transect was estimated as the average of the two closest (range of $0.1-4.0 \mathrm{~km}$ ) rain gauges.

\section{Analytical Approach}

To assess the relationship between vegetation change and grazing systems while accounting for variation associated with precipitation and mesquite cover, we used a split-plot analysis of variance with year as the split (Wilm 1945), grazing system (YL and SR) as the main effect, and precipitation and mesquite cover as covariates. To avoid pseudoreplication (sensu Hulbert 1984), the pastures were the experimental units, and vegetation values were the average of the 10 
Table 2. Pearson product-moment correlation coefficient $(r)$ between plant variable and type of precipitation (mm). 2-yr and 3-yr represent cumulative $2-y r$ and $3-y r$ values leading to vegetation measurement. ${ }^{1}$

\begin{tabular}{|c|c|c|c|c|c|c|}
\hline \multirow[b]{2}{*}{ Response variable } & \multicolumn{6}{|c|}{ Precipitation parameter } \\
\hline & Current summer & 2-yr summer & 3 -yr summer & Current annual & 2-yr annual & 3-yr annual \\
\hline \multicolumn{7}{|l|}{ Plant density } \\
\hline Perennial grasses & -0.08 & 0.12 & 0.08 & $0.34^{\star 2}$ & $0.19^{*}$ & 0.16 \\
\hline Native grasses & $-0.15^{2}$ & -0.12 & -0.09 & 0.09 & 0.02 & -0.04 \\
\hline Forage grasses & 0.22 & 0.11 & 0.14 & $0.32^{*}$ & $0.46^{\star 2}$ & $0.40^{*}$ \\
\hline D. californica & 0.08 & 0.00 & 0.03 & $0.30^{*}$ & $0.39 * 2$ & $0.32^{*}$ \\
\hline Aristida spp. & 0.02 & -0.05 & 0.08 & 0.07 & $0.15^{2}$ & 0.14 \\
\hline B. rothrockii & $-0.29 \star 2$ & $-0.23^{*}$ & $-0.26^{*}$ & -0.06 & -0.20 & $-0.25^{\star}$ \\
\hline Nonnative grasses & 0.06 & $0.26^{\star}$ & 0.18 & $0.30 * 2$ & 0.20 & 0.22 \\
\hline E. lehmanniana & 0.06 & $0.26^{*}$ & 0.18 & $0.30 * 2$ & 0.20 & 0.22 \\
\hline I. tenuisecta & -0.08 & 0.08 & $-0.18^{1}$ & -0.04 & 0.00 & -0.04 \\
\hline \multicolumn{7}{|l|}{ Plant cover } \\
\hline Total shrubs & $0.47^{\star}$ & $0.56^{*}$ & $0.56^{\star}$ & $0.61^{\star 2}$ & $0.51^{*}$ & $0.53^{*}$ \\
\hline I. tenuisecta & $0.40^{\star}$ & $0.39^{*}$ & $0.33^{*}$ & $0.57^{\star}$ & $0.59 * 2$ & $0.52^{*}$ \\
\hline P. velutina & 0.20 & $0.31^{*}$ & $0.35^{\star 2}$ & 0.19 & 0.08 & 0.17 \\
\hline Perennial grasses & $-0.30^{\star 2}$ & 0.02 & -0.08 & 0.17 & 0.07 & 0.05 \\
\hline Native grasses & $-0.39^{\star 2}$ & -0.15 & -0.24 & 0.23 & -0.03 & -0.08 \\
\hline Forage grasses & -0.24 & 0.04 & -0.08 & $0.35^{\star 1}$ & 0.12 & 0.08 \\
\hline Nonnative grasses & -0.05 & 0.22 & 0.17 & 0.20 & 0.23 & $0.25^{2}$ \\
\hline
\end{tabular}

${ }^{1}$ Level of significance: ${ }^{*} P \leq 0.05$.

${ }^{2}$ Precipitation parameter with the greatest correlation with the response variable and was selected as the precipitation covariate for that response variable in the analysis of variance.

transects per pasture. Separate analyses were performed for the short-term period (1972-1984 for density and 1975-1984 for shrub cover) and the long-term period (1972-2006 for density and 1975-2006 for shrub cover), and for the 22-yr period (1984-2006) for grass basal cover. The mesquite covariate was not included in the analyses of $P$. velutina and total shrubs because it was not independent of those response variables.

We used the split-plot analysis instead of the multivariate repeated measurements analysis because it preserved enough degrees of freedom to include two covariates. This decision resulted in an analysis that was not only conservative but also rigorous and fully supported by upholding statistical assumptions of independence, correcting for sphericity violations (Algina and Keselman 1997) and avoiding pseudoreplication.

Based on the Shapiro-Wilk W-test on the residuals (Shapiro and Wilk 1965), response variables became normal after a log $(Y+1)$ transformation except for nonnative grass density, which was instead square-root transformed. Total shrub and mesquite cover needed no transformation. All data met the homogeneity of variance assumptions using the BrownForsythe test (Sall et al. 2005). We used the Mauchly test for sphericity and made adjustments for violations using the Greenhouse-Geisser correction method (Greenhouse and Geisser 1959).

In our analytical approach the grazing system by year interaction was most important because it indicates that values for a response variable became different between the grazing systems at some time after the study started (implying an accumulation of effects), whereas a simple grazing system main effect without a grazing system by year interaction indicates that the overall mean value of the response variable differed throughout the study period, which suggests that the differences were not affected by implementing the rotational grazing systems (implying a preexisting difference and a lack of cumulative effects). Significant covariate terms indicate a linear relationship between the response variable and the precipitation or mesquite cover covariates. A significant covariate by year interaction term indicates that the relationship between the covariate and vegetation variable was not consistent over time. A simple year effect, without a grazing system by year or covariate by year interaction, indicates that values for the response variable differed between at least two dates.

When grazing system by year interaction or year effects were significant $(P \leq 0.05)$, we used the Tukey-Kramer Honestly Significant Difference multiple comparisons test (Sall et al. 2005 ) to determine which system-year combinations and which years differed. Simple linear regression was used to describe the direction of significant relationships between the covariates and response variables. When the covariate by time interaction was significant, separate regression analyses were performed for each year to identify differences in the relationship between years.

Data analyses were performed using the JMP IN 5.1 statistical package (Sall et al. 2005). We used $P \leq 0.05$ to reject the null hypothesis of no difference between grazing treatments, between years, relationship with covariates and interactions in split-plot analysis; multiple comparisons of means between years; and regression for covariates and interactions. We reported actual values of plant density and cover in the text and figures, but all statistical results were based on data transformed for normality. 
Table 3. P-values from the split-plot ANOVA of vegetation density and cover during short-term (9-yr or 12-yr) and long-term (31-yr or 34-yr) study periods with grazing system (GS) main effect, precipitation (PPT) and mesquite cover (MESQ) covariates, year (YR) as the split, and their interactions. ${ }^{1}$

\begin{tabular}{|c|c|c|c|c|c|c|c|c|}
\hline \multirow[b]{2}{*}{ Response variable } & \multirow[b]{2}{*}{ Study period (yr) } & \multicolumn{7}{|c|}{ Explanatory variables } \\
\hline & & GS & PPT & MESQ & YR & $G S \times Y R$ & $\mathrm{PPT} \times \mathrm{YR}$ & $\mathrm{MESQ} \times \mathrm{YR}$ \\
\hline \multicolumn{9}{|l|}{ Density } \\
\hline \multirow[t]{2}{*}{ Perennial grass } & 12 & $<0.01$ & $<0.01(+)$ & $<0.01(+)$ & 0.85 & 1.00 & 1.00 & 0.94 \\
\hline & 34 & 0.58 & $<0.01(+)$ & $<0.01(+)$ & $<0.01$ & 0.99 & 0.31 & 0.71 \\
\hline \multirow[t]{2}{*}{ Native grass } & 12 & 0.22 & $0.01(-)$ & $<0.01(-)$ & 0.38 & 0.97 & 0.95 & 0.95 \\
\hline & 34 & 0.03 & 0.07 & $<0.01(-)$ & $<0.01$ & 1.00 & 0.84 & 0.99 \\
\hline \multirow[t]{2}{*}{ Forage grass } & 12 & 0.32 & 0.08 & 0.96 & 0.24 & 0.98 & 0.99 & 0.97 \\
\hline & 34 & 0.81 & $<0.01(+)$ & $<0.01(+)$ & $<0.01$ & 1.00 & 1.00 & 0.90 \\
\hline \multirow[t]{2}{*}{ D. californica } & 12 & 0.89 & 0.22 & 0.23 & 0.90 & 0.88 & 0.97 & 0.95 \\
\hline & 34 & 0.68 & $<0.01(+)$ & $<0.01(+)$ & $<0.01$ & 0.99 & 0.83 & 0.85 \\
\hline \multirow[t]{2}{*}{ Aristida spp. } & 12 & 0.05 & 0.62 & 0.60 & 0.36 & 0.99 & 0.98 & 0.94 \\
\hline & 34 & 0.01 & $<0.01(-)$ & $0.04(-)$ & $<0.01$ & 0.98 & 0.98 & 0.87 \\
\hline \multirow[t]{2}{*}{ B. rothrockii } & 12 & 0.38 & 0.27 & 0.02 & 0.56 & 0.96 & 0.96 & 0.96 \\
\hline & 34 & 0.24 & $<0.01(-)$ & 0.26 & 0.08 & 0.98 & 0.98 & 1.00 \\
\hline \multirow{2}{*}{ Nonnative grass } & 12 & 0.54 & $0.03(+)$ & 0.53 & 0.73 & 1.00 & 0.97 & 1.00 \\
\hline & 34 & 0.33 & $<0.01(+)$ & 0.68 & $<0.01$ & 0.98 & 0.14 & 0.32 \\
\hline \multirow{2}{*}{ E. lehmanniana } & 12 & 0.54 & $0.03(+)$ & 0.61 & 0.73 & 1.00 & 0.99 & 1.00 \\
\hline & 34 & 0.50 & $<0.01(+)$ & 0.53 & $<0.01$ & 1.00 & 0.12 & 0.31 \\
\hline \multirow[t]{2}{*}{ 1. tenuisecta } & 12 & 0.53 & $0.01(-)$ & $0.05(-)$ & 0.13 & 0.96 & 0.98 & 1.00 \\
\hline & 34 & 0.64 & 0.46 & 0.97 & 0.03 & 1.00 & 0.75 & 0.95 \\
\hline \multicolumn{9}{|l|}{ Shrub cover } \\
\hline \multirow[t]{2}{*}{ Total shrubs } & 9 & 0.73 & 0.68 & - & $<0.01$ & 0.99 & 0.92 & - \\
\hline & 31 & 0.38 & $0.03(+)$ & - & $<0.01$ & 0.98 & 0.73 & - \\
\hline \multirow[t]{2}{*}{ P. velutina } & 9 & 0.72 & $<0.01(+)$ & - & 0.01 & 0.81 & 0.55 & - \\
\hline & 31 & 0.47 & $<0.01(+)$ & - & $<0.01$ & 0.74 & 0.85 & - \\
\hline \multirow[t]{2}{*}{ I. tenuisecta } & 9 & 0.02 & $<0.01(-)$ & $<0.01(-)$ & $<0.01$ & 0.74 & 0.11 & 0.22 \\
\hline & 31 & 0.73 & $0.03(-)$ & $0.05(-)$ & $<0.01$ & 0.82 & 0.11 & 0.02 \\
\hline
\end{tabular}

${ }^{1}(+)$ and $(-)$ adjacent to $P$-values of covariates show the direction of correlation with the response variable.

\section{RESULTS}

\section{Grass Density}

The application of different grazing systems did not correspond to changes in grass density in either the 12-yr short-term (19721984) or the 34-yr long-term (1972-2006) periods as shown by the absence of any significant grazing system by year interactions (Table 3). However, in both the short- and longterm periods, there were differences in the density of Aristida spp. between the grazing systems that predated and persisted through their application as shown by a significant grazing system main effect. Aristida spp. was greater for SR than YL in the short-term period $\left(\mathrm{SR} \bar{x}=4.71 \cdot \mathrm{m}^{-2}, \mathrm{SE}=0.15\right.$; YL $\bar{x}=$ $\left.1.91 \cdot \mathrm{m}^{-2}, \mathrm{SE}=0.27\right)$ and long-term period $\left(\mathrm{SR} \bar{x}=2.71 \cdot \mathrm{m}^{-2}\right.$, $\left.\mathrm{SE}=0.09 ; \mathrm{YL} \bar{x}=0.99 \cdot \mathrm{m}^{-2}, \mathrm{SE}=0.11\right)$. A grazing system main effect was detected only in the short-term period for perennial grasses $\left(\mathrm{SR} \quad \bar{x}=16.49 \cdot \mathrm{m}^{-2}, \mathrm{SE}=0.10 ; \mathrm{YL} \bar{x}=\right.$ $\left.22.60 \cdot \mathrm{m}^{-2}, \mathrm{SE}=0.19\right)$ and in the long-term period for native grasses $\left(\mathrm{SR} \bar{x}=10.68 \cdot \mathrm{m}^{-2}, \mathrm{SE}=0.09 ; \mathrm{YL} \bar{x}=7.43 \cdot \mathrm{m}^{-2}, \mathrm{SE}=\right.$ $0.12)$.

Across both time periods the precipitation and mesquite cover covariates were positively correlated with perennial grasses, but nonnative grasses and E. lehmanniana were positively correlated with precipitation only (Table 3). Native grass was negatively correlated with both covariates in the short-term period, but only with mesquite cover in the long term. In the long-term period only, both covariates were positively correlated with forage grasses and D. californica and negatively correlated with Aristida spp.; but B. rothrockii had a negative relationship with precipitation only.

Changes over time (year effects) were never significant in the short-term period, but significant changes occurred in the longterm period for all species and groups except B. rothrockii (Table 3). Between 1991 and 2006 overall densities decreased to very low values for all these species and groups; but in the short term (1972-1984) values remained relatively stable (Fig. 2). The largest increase in E. lehmannina occurred between 1984 and 1991.

\section{Shrub Density and Cover}

I. tenuisecta density was not related to the application of different grazing systems in either the 12-yr (1972-1984) or the 34-yr (1972-2006) periods as shown by the lack of a significant grazing system by year interaction, and the density did not differ between grazing systems in either time period based on the lack of a significant grazing system main effect (Table 3). I. 

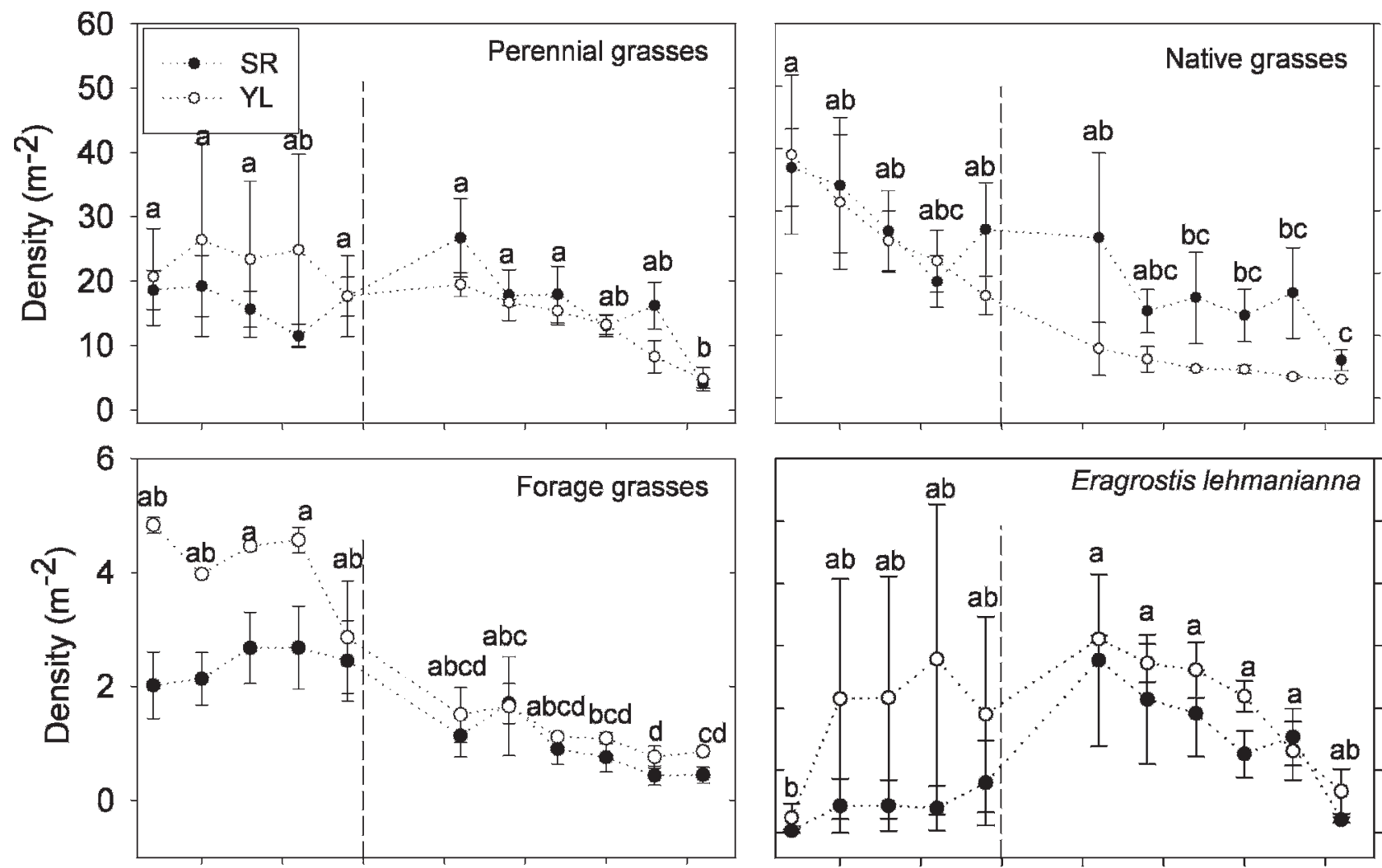

25

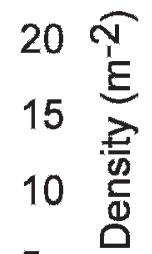

5

0

30

25

$\begin{array}{ll}20 & \text { Tั } \\ 15 \\ 10 \\ 5\end{array}$

5

0
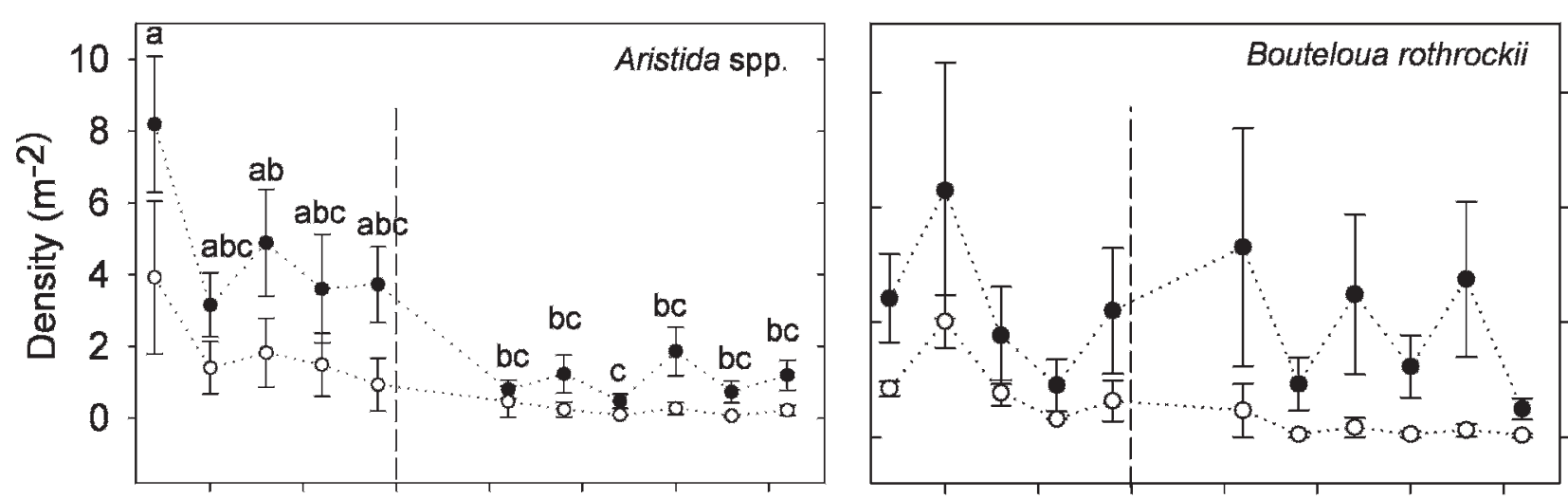

15
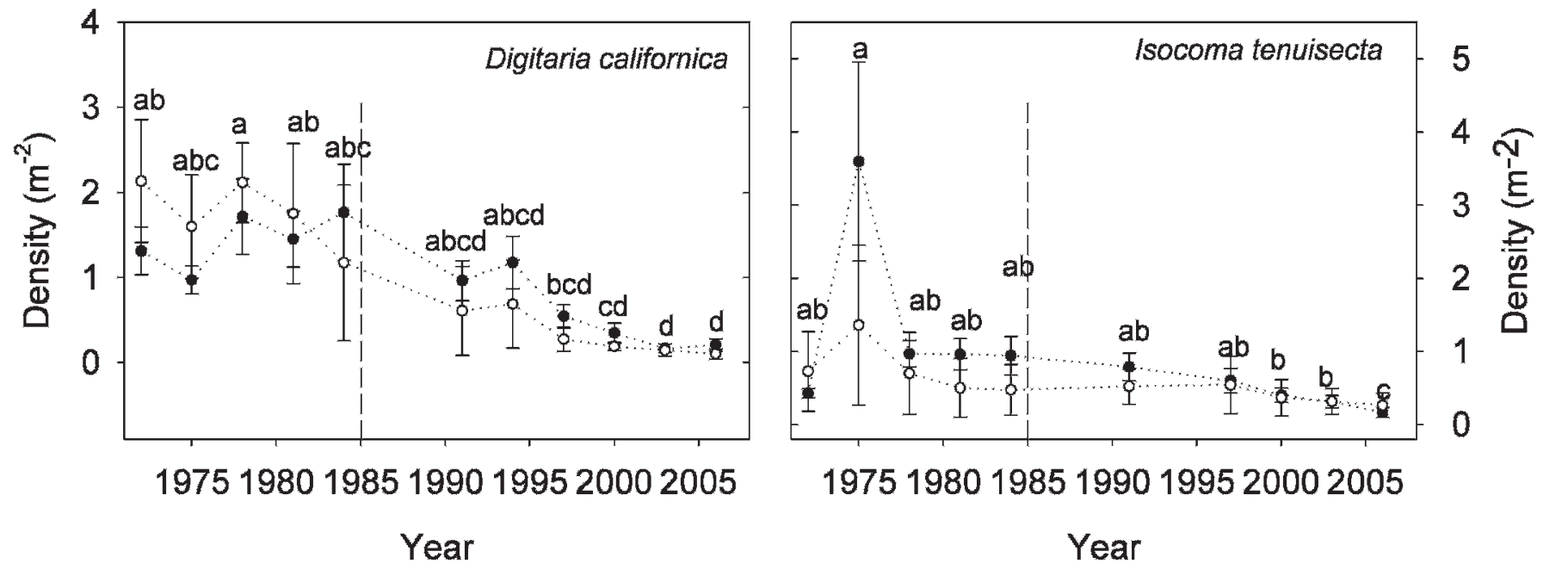

Figure 2. Density of perennial grasses, native grasses, forage grasses, E. lehmanniana, Aristida spp., B. rothrockii, D. californica, and I. tenuisecta in the two grazing systems (seasonal rotation $[S R]=$ solid circles, and yearlong $[Y L]=$ open circles) between 1972 and 2006 . The vertical broken line shows the end of the short-term period in 1985. Different letters above the single SE bars indicate years with significantly different $(P \leq 0.05)$ plant density after combining grazing treatments. 


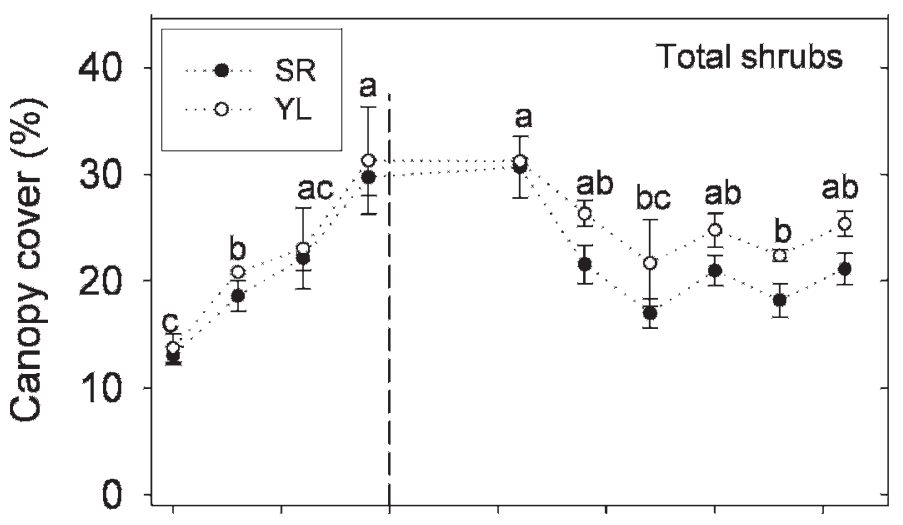

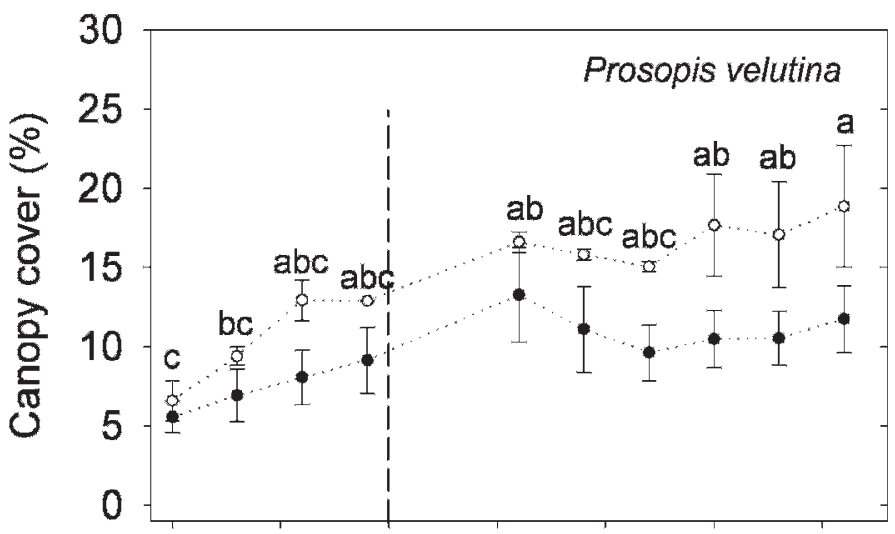

1975198019851990199520002005

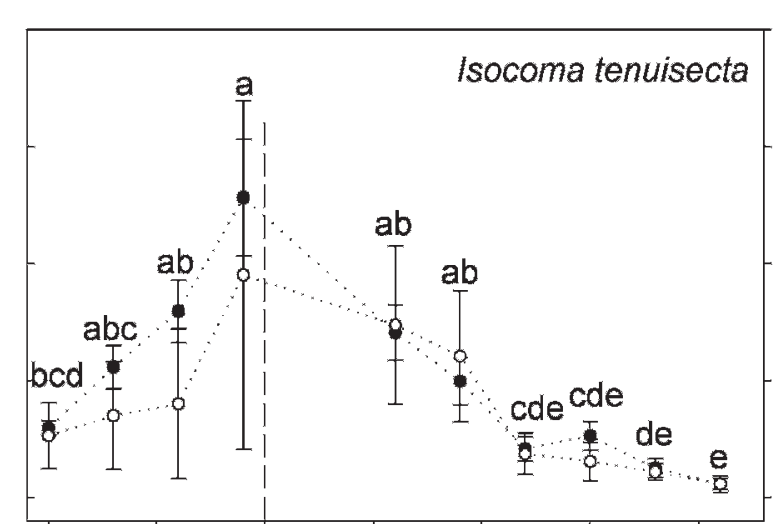

1975198019851990199520002005

\section{Year}

\section{Year}

Figure 3. Percentage cover of total shrubs, I. tenuisecta, and $P$. velutina, in the two grazing systems (seasonal rotation [SR] $=$ solid circles, and yearlong $[\mathrm{YL}]=$ open circles) between 1975 and 2006. The vertical broken line shows the end of the first nine years. Different letters above the single SE bars indicate years with significantly different $(P \leq 0.05)$ cover after combining grazing treatments.

tenuisecta density had a negative correlation with both covariates only in the short-term (Table 3). Changes over time (year effects) were significant in the long-term period only, when density declined to near zero by 2006 (Fig. 2).

Changes in total shrub, $P$. velutina, and $I$. tenuisecta cover were not related to the application of different grazing systems in either the 9-yr short-term (1975-1984) or the 31-yr longterm (1975-2006) periods as shown by the lack of a significant grazing system by year interaction (Table 3). However, in the short-term period, I. tenuisecta cover was greater in the SR than YL grazing system (SR $\bar{x}=7.33 \%, S E=0.06$; YL $\bar{x}=4.91 \%, \mathrm{SE}=0.11)$. Precipitation was positively correlated with $P$. velutina cover in both the short- and long-term periods, but only with total shrub cover in the short term (Table 3). I. tenuisecta cover was negatively correlated with both covariates (precipitation and mesquite cover) in the short term but had a mesquite by year interaction in the long term where the slope was positive in 1975,2003 , and 2006, but negative in all other years (Table 3 ). In both the short- and long-term periods, cover of total shrub, P. velutina, and I. tenuisecta changed over time (Table 3). Between 1975 and 1991, total shrub and P. velutina cover increased but remained relatively stable thereafter, but $I$. tenuisecta increased through 1984 and then declined to near zero by 2006 (Fig. 3).

\section{Grass Cover}

The application of different grazing systems did not correspond to changes in grass cover over the 22-yr period (1984-2006), as shown by the lack of a significant grazing system by year interaction (Table 4). However, perennial grass cover was less in the SR than YL grazing system ( $\mathrm{SR} \bar{x}=2.04 \%, \mathrm{SE}=0.06$; YL $\bar{x}=2.96 \%, \mathrm{SE}=0.11$ ), as shown by a significant grazing system main effect (Table 4). Nonnative grass cover was positively correlated with precipitation (Table 4). Cover in all four groups changed over time (Table 4), where cover increased from 1984 to 1991 and declined to 1984 values between 1994 and 2006 (Fig 4).

\section{DISCUSSION}

\section{Grazing Systems}

There were no detectable differences in vegetation between the SR and YL grazing systems in either the short-term (12-yr) or long-term (34-yr) periods even after accounting for spatial gradients of precipitation and mesquite cover. Either the grazing systems do not produce different effects or the effects are small and have not yet accumulated to a detectable level. 
Table 4. P-values from the split-plot analysis of grass basal cover over $22 \mathrm{yr}$ (1984-2006) with grazing system (GS) main effect, precipitation (PPT) and mesquite cover (MESQ) covariates, year (YR) as the split, and their interactions. ${ }^{1}$

\begin{tabular}{|c|c|c|c|c|c|c|c|}
\hline \multirow[b]{2}{*}{ Grass response variables } & \multicolumn{7}{|c|}{ Explanatory variables } \\
\hline & GS & PPT & MESQ & YR & $\mathrm{GS} \times \mathrm{YR}$ & $\mathrm{PPT} \times \mathrm{YR}$ & MESQ $\times$ YR \\
\hline Perennial & $<0.01$ & 0.94 & 0.27 & $<0.01$ & 0.49 & 0.88 & 0.74 \\
\hline Native & 0.07 & 0.13 & 0.28 & $<0.01$ & 0.96 & 0.96 & 1.00 \\
\hline Forage & 0.11 & 0.37 & 0.95 & $<0.01$ & 0.77 & 0.82 & 1.00 \\
\hline Nonnative & 0.92 & $<0.01(+)$ & 0.43 & $<0.01$ & 0.95 & 0.23 & 0.13 \\
\hline
\end{tabular}

${ }^{1}(+)$ adjacent to $P$-values of covariates shows the direction of correlation with the response variable.

The absence of a detectable rotational grazing effect on vegetation changes may result from the overriding influences of grazing intensity, length of grazing periods, pasture size, precipitation variability, and few replicates. The SR system was based on positive results from a short-term, plot-scale study where defoliation intensities were lower for seasonal rotation than for yearlong grazing (Martin 1973). However, as applied to this study, defoliation intensity was 3.0 times greater during the grazing periods in the SR system than the YL system. Even though generous rest periods followed SR grazing, the rest may not have been sufficient to improve vegetation conditions after such long periods of intense defoliation (see review in
Briske et al. 2008). Van Poollen and Lacey's (1979) conclusion that grazing intensity has a greater influence on vegetation response than seasonal rotation may apply here. Rotational grazing is expected to benefit forage species because it reduces their selected use (Kirkman and Moore 1995; Teague and Dowhower 2003), but our large pastures (400-1 800 ha) may have precluded that benefit (e.g., Bailey et al. 1996; Norton 1998) despite the periodic intense use.

The impacts of the recurring dry periods on vegetation may have limited the influence of the seasonal rotation treatment because when dry periods become droughts, there may be little benefit of seasonal rotation grazing systems (Teague et al.
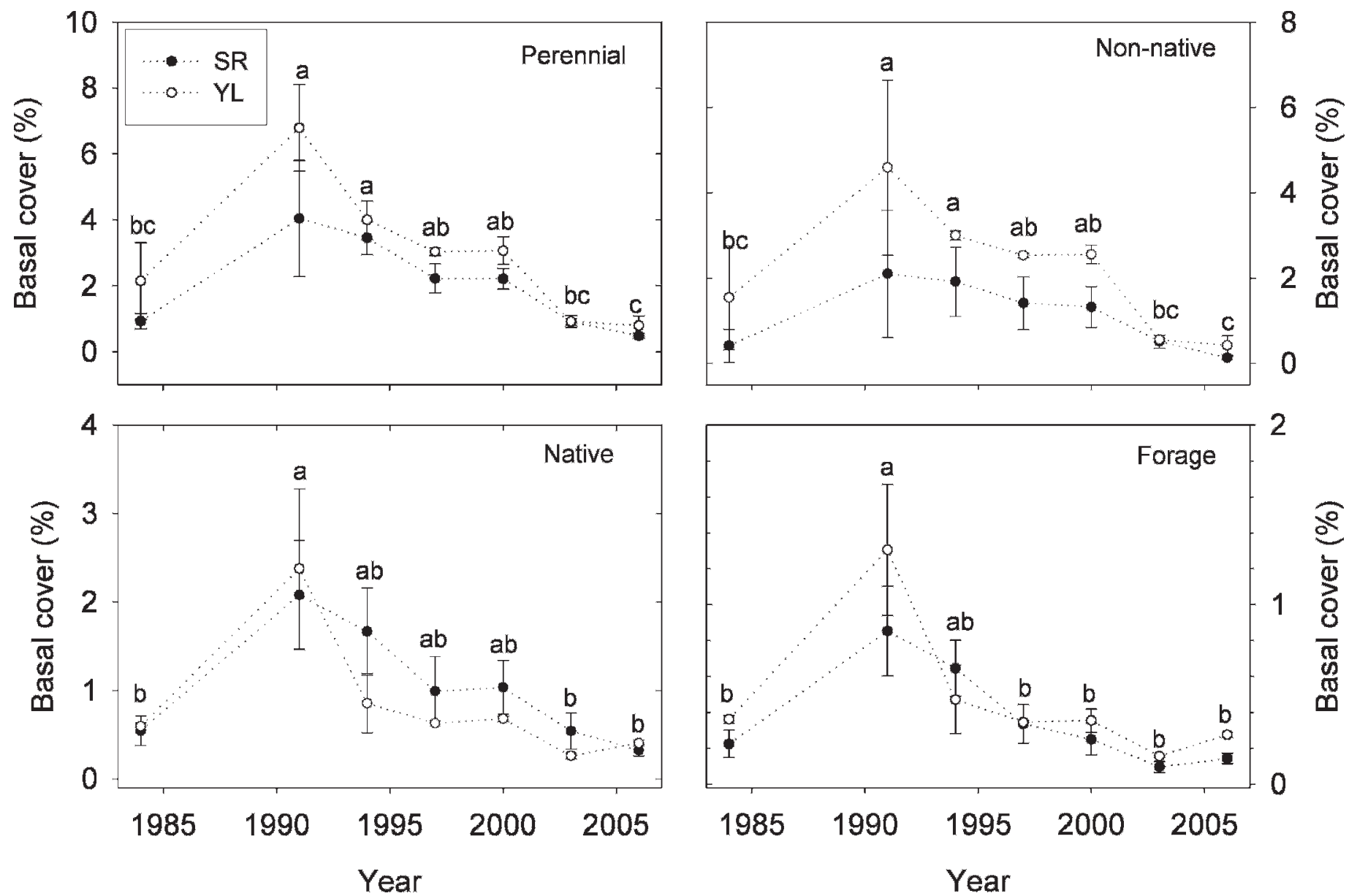

Figure 4. Basal cover for four perennial grass groups in the two grazing systems (seasonal rotation $[S R]=$ solid circles, and yearlong $[Y L]=0 p e n$ circles), 1984-2006. Different letters above the single SE bars indicate years with significantly different $(P \leq 0.05)$ cover after combining grazing treatments. 
2004). Drought is common on our study area (Fig. 1), and during the prolonged drought since 1994, grass density and cover declined equally under both the SR and YL systems.

The power to detect differences between grazing systems was low because there were few pasture replicates. For example, we performed a conservative power analysis for perennial grass density by quadrupling the number of pastures (increased from 2 to $8 \mathrm{YL}$ and 5 to $20 \mathrm{SR}$ pastures) through the simple replication of values collected from the study pastures. In spite of this conservative estimate of variance, we detected a significant grazing system by year interaction only in 1991 (SR $\bar{x}=26.75 \cdot \mathrm{m}^{-2}$; YL $\bar{x}=19.47 \cdot \mathrm{m}^{-2}$ ), but that difference did not persist during the dry period beginning in 1994 .

It remains a possibility that more time is needed to detect the small but accumulating grazing system effect, and those situations where the effects do not persist through dry conditions. In nearby arid locations, Valone et al. (2002) reported vegetation differences between grazed and ungrazed areas $39 \mathrm{yr}$ after livestock exclusion but not after $20 \mathrm{yr}$, whereas in observations over $56 \mathrm{yr}$, there were temporary (persisting for $1 \mathrm{yr}, 6 \mathrm{yr}$, or $20 \mathrm{yr}$ ) differences in some vegetation attributes that occurred as early as $9 \mathrm{yr}$ and as late as $50 \mathrm{yr}$ after grazing exclusion (Havstad et al. 1999). In arid and semiarid ecosystems, difficulties in detecting management influences on vegetation dynamics arise from the inherently slow rates of vegetation response due to slow turnover of resources, and rapid but temporary responses to high interannual variability of precipitation (e.g., Milchunas et al. 1994; Milchunas and Lauenroth 1995; O'Connor and Roux 1995). Frequently measuring numerous replicates over many years may be the only means of detecting responses to management practices in these ecosystems.

The significant grazing system main effects we found were remnants of the pastures being different before the research began, and those differences persisted through the application of the grazing treatments. We concentrated our interpretation at the soil-ecological site level (Taylor et al. 1993) because precipitation and mesquite cover effects are already accounted for as covariates in our analytical model. The transects in the SR pastures were predominantly $(50 \%)$ on sandy-loam deep ecological sites, whereas YL pastures were dominated by $(35 \%)$ sandy-loam upland sites (Table 1). Greater density of the shortlived Aristida spp. in SR pastures is consistent with the lower water-holding capacity and drought-prone conditions on sandy-loam deep sites, whereas greater perennial grass cover in YL pastures is consistent with the greater persistence of soil moisture on sandy loam upland sites (Martin and Severson 1988; USDA, NRCS 2003).

\section{Precipitation and Mesquite Covariates}

The precipitation and mesquite cover covariates improved our analyses by accounting for previously unexplained variation. Even though the two covariates were correlated $\left(R^{2}\right.$ of 0.70 in short term and 0.76 in long term), we retained both in our analysis because the proportion of explained variance increased by up to $24 \%$ with the addition of the second covariate, and there are strong theoretical bases that these environmental factors influence vegetation dynamics through different mechanisms.
The persistent long-term positive relationships with both covariates (precipitation and mesquite cover) and density of perennial grass, forage grass, and D. californica most likely reflect the stronger influence of increasing precipitation at higher elevation pastures because maximum mesquite cover was $<25 \%$ (Martin and Severson 1988; McClaran and Angell 2006). Similarly, the persistent negative relationships between the covariates and Aristida spp. density and I. tenuisecta cover reflects a long-observed pattern of greater abundance in drier settings and little response to mesquite cover of $<25 \%$ (Martin and Severson 1988; McClaran and Angell 2006).

The relationship between the covariates and eight vegetation variables changed between the short- and long-term periods: from negative to no relationship for native grass and $I$. tenuisecta densities, from no relationship to positive for forage grass and D. californica densities and total shrub cover, and from no relationship to negative for Aristida spp. and $B$. rothrockii densities. The long-term decline of native grass species and I. tenuisecta may have contributed to the absence of any relationship in that period. In contrast, the detection of any relationships with covariates in the long term may occur from the additional degrees of freedom from seven additional years of observation (e.g., Ramsey and Schafer 2002).

Relationships with the precipitation covariate provide opportunities to estimate responses to the climate changes predicted for the southwestern United States. Recent climate models (Christensen and Hewitsen 2007) predict 5-10\% less precipitation and a $2-4^{\circ} \mathrm{C}$ increase by the end of this century, which suggests that the density of forage grasses, D. californica, density and cover of the nonnative E. lehmanniana, and cover of $P$. velutina will decline at all elevations, but I. tenuisecta and Aristida spp. may increase at higher elevations. We cannot comment on any differences in the outcome of vegetation response to grazing systems under different climatic conditions because our analytical model did not have enough degrees of freedom to include a grazing system by precipitation interaction.

\section{Temporal Dynamics}

Detectable temporal changes (as shown by year effects without interactions) in the density of six grass species and groups only after long-term observation is consistent with changes that occur slowly in arid and semiarid ecosystems (e.g., Havstad et al. 1999; Valone et al. 2002). For grass density and cover, the clear trend was a reduced abundance since 1984-1991. This was independent of grazing treatment and the mesquite cover and precipitation covariates. The simultaneous decline of native grasses and increase of E. lehmanniana between 1984 and 1991 is the result of highly successful lovegrass recruitment (invasion) rather than the hastened death of adult native grasses (Angell and McClaran 2001), whereas the decline of nearly all grasses since 1991 may be the result of dry summer conditions since then (Fig. 1), possibly combined with reduced nitrogen availability because nitrogen use-efficiency is low for E. lehmanniana (Fernandez-Gimenez and Smith 2004). These patterns were probably not strongly influenced by the increase of mesquite cover because it has not reached levels thought to strongly inhibit grasses (McClaran and Angell 2006, 2007).

Temporal changes in shrub cover were observed in both the short- and long-term periods, suggesting that these changes are 
more rapid and more persistent than changes in grass density. The slow or lack of increase of P. velutina cover since 1991, compared to its steady increase earlier, may signal a landscape carrying capacity that is constrained by precipitation (e.g., Glendening 1952; House et al. 2003; Sankran et al. 2005; Browning et al. 2008). The increase and then decline of $I$. tenuisecta density and cover may begin with wet winters and end when death results from dry conditions or old age, because neighboring grass and $P$. velutina and livestock grazing have not prevented new eruptions (McClaran 2003). The cyclic pattern is similar to short-lived snakeweed (Gutierrezia sarothrae [Pursh] Britt. \& Rusby) in the Chihuahuan Desert grasslands of New Mexico (Torrel et al. 1992).

It is not surprising that the abundances of $P$. velutina and the nonnative E. lehmanniana were unrelated to grazing management systems because they are examples of threshold-type changes that are not likely to respond to the application of new grazing management practices (Westoby et al. 1989; Briske et al. 2003). P. velutina has increased in density and cover following cessation of fire and the ubiquitous dispersal of seed by livestock beginning around 1880 , and the subsequent manipulation of livestock has not altered this pattern (see review in McClaran 2003). The presence of livestock grazing may hasten the spread of E. lehmanniana (Bock et al. 2007), but the eventual abundance will be independent of livestock use or use intensity (McClaran and Anable 1992; Angel and McClaran 2001).

Our ability to distinguish equilibrium from nonequilibrium dynamics is limited by our analytical model, the structure of the covariates, and similar grazing pressures in the yearlong (YL) and seasonal rotation (SR) treatments. Evidence supporting nonequilibrium dynamics include high interannual variation in precipitation, B. rothrockii and E. lehmanniana dynamics that were related to precipitation (external driver) but not mesquite (internal competition), and the absence of a grazing system by time interaction (weak coupling of plant-herbivore interaction; Ellis and Swift 1988; Briske et al. 2003). However, because of limited degrees of freedom, our analytical model did not include grazing by precipitation or grazing by mesquite interactions, and the covariates (precipitation and mesquite) represent multiyear spatial gradients rather than interannual variation. Therefore, we are not able to distinguish the relative influence of interannual precipitation versus grazing system (plant-herbivore coupling) or mesquite (internal competition). This is particularly true for the dynamics of D. californica, Aristida spp., and I. tenuisecta, which were related to both precipitation and mesquite. Our ability to distinguish the relative influence of biotic (grazing pressure) versus abiotic (precipitation) factors on vegetation dynamics is limited because utilization was similar at $\sim 50 \%$ for both SR and YL grazing treatments. A more relevant design would include measures along a gradient of grazing intensities.

Maintaining and Improving Long-Term Grazing System Studies This 34-yr grazing system study is unusually long (Briske et al. 2008), but the reassignment of 5 of the 12 original pastures to different studies shows that maintaining the full study design was not the highest priority for pasture allocations on the Santa Rita Experimental Range. We believe that the continued allocation of seven original pastures occurred because 1) grazing rotations and vegetation measurements were simple and infrequent, 2) abundant opportunities were available to establish new research projects in alternative locations, and 3) a livestock cooperator and a succeeding rangeland scientist were willing to continue the protocols established by others.

Increasing the number of pastures and strategic location of sample transects relative to ecological sites and distance to water could improve the ability to detect differences in vegetation created by these grazing systems. If more pastures were created by reducing pasture size, then some attention will be needed to establish a minimum pasture size that will not affect grazing behavior (Bailey et al. 1996; Norton 1998). Improved detection may also occur if more transects were established to account for the spatial variation related to ecological sites (i.e., soils) and grazing intensity at increasing distances from water developments (Briske et al. 2008).

\section{IMPLICATIONS}

Based on vegetation change, there was no detectable advantage to using the seasonal rotation grazing system over the yearlong grazing. From the land manager's perspective, it does not matter whether the absence of a detectable effect is because the systems do not differ or the effect is too small and has yet to reach a detectable level. In either case the extra effort of implementing a seasonal rotation grazing system did not produce a change in the vegetation within $34 \mathrm{yr}$.

In addition to planning for the long-term maintenance of grazing systems studies, the power to detect treatment effects would be increased by including covariates such as precipitation and overstory vegetation because of their conservative use of degrees of freedom, and by strategically locating sample transects to account for spatial variation due to ecological sites and distance from livestock water developments.

Different short- and long-term relationships between vegetation and the precipitation and mesquite cover covariates have implications for vegetation classification systems and predicting response to mesquite management. For example, differences in the strength of the precipitation gradient between the shortand long-term periods can help define the range of variability incorporated into ecological site descriptions.

\section{ACKNOWLEDGMENTS}

Funding from the USDA Forest Service Rocky Mountain Research Station and the Arizona Agricultural Experiment Station supported this research. Data sets were provided by the Santa Rita Experimental Range Digital Database (http://ag.arizona.edu/srer). Funding for the digitization of these data and for their analysis in this paper was provided by the U.S. Department of Agriculture Forest Service Rocky Mountain Research Station, and the University of Arizona Agricultural Experiment Station. Two anonymous reviewers provided valuable suggestions that improved the manuscript.

\section{LITERATURE CITED}

Algina, J., and H. J. Keselman. 1997. Detecting repeated measures effects with univariate and multivariate statistics. Psychological Methods 2:208-218. 
Angell, D. L., and M. P. McClaran. 2001. Long-term influences of livestock management and non-native grass on grass dynamics in the Desert Grassland. Journal of Arid Environments 49:507-520.

Bailey, D. W., J. E. Gross, E. A. Laca, L. R. Rittenhouse, M. B. Coughenour, D. M. Swift, And P. L. Simms. 1996. Mechanisms that result in large herbivore grazing patterns. Journal of Range Management 49:386-400.

Bock, C. E., J. H. Bock, L. Kennedy, And Z. F. Jones. 2007. Spread of non-native grasses into grazed versus ungrazed desert grasslands. Journal of Arid Environments 71:229-235.

BreckenfieLd, D. J., And D. Robinett. 2003. Soil and ecological sites of the Santa Rita Experimental Range. In: M. P. McClaran, P. F. Ffolliot, and C. B. Edminister [EDs.]. Santa Rita Experimental Range: 100 years (1903-2003) of accomplishments and contributions; conference proceedings; October 30-November 1 2003; Tucson, AZ, USA; Proc. RMRS-P-30. Ogden, UT, USA: US Department of Agriculture Forest Service, Rocky Mountain Research Station. p. $157-165$

BRISKE, D. D. 1991. Developmental morphology and physiology of grasses. In: R. K. Heitshmidt and J. W. Stuth [EDS.]. Grazing management: an ecological perspective. Portland, OR, USA: Timbers Press. p. 85-108.

Briske, D. D., J. D. Derner, J. R. Brown, S. D. Fuhlendorf, W. R. Teague, K. M. Havstad, R. L. Gillen, A. J. Ash, and W. D. Willms. 2008. Rotational grazing on rangelands: reconciliation of perception and experimental evidence. Rangeland Ecology and Management 61:3-17.

Briske, D. D., S. D. Funlendorf, and F. E. Smeins. 2003. Vegetation dynamics on rangelands: a critique of the current paradigms. Journal of Applied Ecology 40:601-614

Browning, D. M., S. R. Archer, G. P. Asner, M. P. McClaran, and C. A. Wessman. 2008. Woody plants in grasslands: post-encroachment stand dynamics. Ecological Applications 18:928-944.

Cable, D. R. 1975. Influence of precipitation on perennial grass production in the semidesert southwest. Ecology 56:981-986.

Christensen, J. H., and B. Hewitson. 2007. Regional climate projections. In: S. Solomon, D. Qin, M. Manning, M. Marquis, K. Averyt, M. M. B. Tignor, H. L. Miller, Jr., and Z. Chen [EDS.]. Climate change 2007: the physical science basis. Cambridge, United Kingdom: Cambridge University Press. p. 847-940.

ElıIS, J. E. 1994. Climate variability and complex ecosystem dynamics: implications for pastoral development. In: I. Scoones [ED.]. Living with uncertainty: new directions in pastoral development in Africa. London, United Kingdom: Intermediate Technology Publications. p. 37-46.

ElLIS, J. E., AND D. M. Swift. 1988. Stability of African pastoral ecosystems: alternate paradigms and implications for development. Journal of Range Management 41:450-459.

Fernandez-Gimenez, M. E., and S. E. Smith. 2004. Nitrogen effects on Arizona cottontop and Lehmann lovegrass seedlings. Journal of Range Management 57:76-81.

Funlendorf, S. D., D. D. Briske, and F. E. Smeins. 2001. Herbaceous vegetation change in variable rangeland environments: the relative contribution of grazing and climatic variability. Applied Vegetation Science 4:177-186.

Fynn, R. W. S., And T. G. O'Connor. 2000. Effects of stocking rate and rainfall on rangeland dynamics and cattle performance in semi-arid savanna. South African Journal of Applied Ecology 37:491-507.

Gibbens, R. P., K. M. Havstad, D. D. Billlheimer, and C. H. Herbel. 1993. Creosote vegetation after 50 years of lagomorph exclusion. Oecologia 94:210-217.

GLendening, G. E. 1952. Some quantitative data on the increase of mesquite and cactus on a desert grassland range in southern Arizona. Ecology 33:319-328.

Greenhouse, S. W., and S. Geisser. 1959. On the methods in the analysis of profile data. Psychometrika 24:95-112

Havstad, K. M., R. P. Gibbens, C. A. Knorr, and L. W. Murray. 1999. Long term influences of shrub removal and lagomorph exclusion on the Chihuahuan Desert vegetation dynamics. Journal of Arid Environments 42:155-166.

HeADY, H. F. 1961. Continuous vs. specialized grazing systems: a review and application of the California annual type. Journal of Range Management 14:182-193.

Hoffman, M. T., G. D. BarR, And R. M. Cowling. 1990. Vegetation dynamics in the semi-arid eastern Karoo, South Africa: the effects of seasonal rainfall and competition on grass and shrub basal cover. South African Journal of Science 86:462-463.

House, J. I., S. Archer, D. D. Breshears, and R. J. Scholes nCEAS Tree-Grass Interaction Participants. 2003. Conundrums in mixed woody-herbaceous plant systems. Journal of Biogeography 30:1763-1777.

Hulbert, S. H. 1984. Pseudoreplication and the design of ecological field experiments. Ecological Monographs 54:187-211.

Khumalo, G., J. Holechek, M. Thomas, and F. Molinar. 2007. Long-term vegetation productivity and trend under two stocking levels on Chihuahuan desert rangeland. Rangeland Ecology and Management 60:165-171.

Kirkman, K. P., And A. Moore. 1995. Towards improved grazing management recommendations for sourveld. African Journal of Range and Forage Science 12:135-144

Livingston, M., B. A. Roundy, and S. E. Smith. 1997. Association of overstory plant canopies and native grasses in southern Arizona. Journal of Arid Environments 35:441-449.

Martin, S. C. 1973. Responses of semi desert grasses to seasonal rest. Journal of Range Management 26:165-170.

Martin, S. C., and K. S. Severson. 1988. Vegetation response to the Santa Rita grazing system. Journal of Range Management 41:291-295.

Mathew, C., S. G. Assuero, C. K. Black, N. Sackville, and R. Hamilton. 2000. Tiller dynamics of grazed swards. In: G. Lemaire, J. Hodgson, A. Moraes, P. C. F. Carvalho, and C. Nabinger [EDS.]. Grassland ecophysiology and grazing ecology. Wallingford, United Kingdom: CAB International. p. 127-150.

McClaran, M. P. 2003. A century of vegetation change on the Santa Rita Experimental Range. In: M. P. McClaran, P. F. Ffolliot, and C. B. Edminister [EDS.]. Santa Rita Experimental Range: 100 years (1903-2003) of accomplishments and contributions; conference proceedings; 30 October-1 November 2003; Tucson, AZ, USA; Proc. RMRS-P-30. Ogden, UT, USA: US Department of Agriculture Forest Service, Rocky Mountain Research Station. p. 16-33.

McClaran, M. P., and M. E. Anable. 1992. Spread of introduced Lehmann lovegrass along a grazing intensity gradient. Journal of Applied Ecology 29:92-98.

McClaran, M. P., and D. L. Angell. 2006. Long-term vegetation response to mesquite removal in desert grassland. Journal of Arid Environments 66:686-697.

McClaran, M. P., and D. L. Angell. 2007. Mesquite and grass relationships at two spatial resolutions. Plant Ecology 191:119-126.

Mllchunas, D. G., J. R. Forwood, and W. K. Lauenroth. 1994. Productivity of longterm grazing treatments in response to seasonal precipitation. Journal of Range Management 47:133-139.

Milchunas, D. G., and W. K. LauenRoth. 1995. Inertia in plant community structure: state and changes after cessation of nutrient-enrichment stress. Ecological Applications 5:452-458.

Norton, B. E. 1998. The application of grazing management to increase sustainable livestock production. Animal Production in Australia 22:15-26.

O'ConnoR, T. G., And P. W. Roux. 1995. Vegetation changes (1949-71) in semiarid, grassy dwarf shrubland in the Karoo, South Africa: influence of rainfall variability and grazing by sheep. Journal of Applied Ecology 32:612-626.

Olson, B. E., AND J. H. Richards. 1988. Annual replacement of the tillers of Agropyron desertorum following grazing. Oecologia 76:1-6.

Palmer, A. R., C. G. Hobson, and M. T. Hoffman. 1990. Vegetation change in the semi-arid succulent dwarf shrubland in the Eastern Cape, South Africa. South African Journal of Science 86:392-395.

Ramsey, F. L., AND D. W. Schafer. 2002. The statistical sleuth: a course in methods and data analysis. 2nd ed. Pacific Grove, CA, USA: Duxbury Press. $742 \mathrm{p}$.

RUYLE, G. B., AND D. J. Young. 1997. Arizona range grasses: their description, forage value and grazing management. Tucson, AZ, USA: University of Arizona Cooperative Extension. 152 p.

Sall, J., L. Creighton, and A. Lehman. 2005. JMP Start Statistics: zguide to statistics and data analysis using JMP and JMP IN software. Cary, NC, USA: SAS Institute. $560 \mathrm{p}$.

Sankran, M., N. P. Hanan, R. J. Scholes, J. Ratnam, D. J. Augustine, B. S. Cade, J. Gignoux, S. I. Higgins, X. Le Roux, F. Ludwig, J. Ardo, F. Banyikwa, A. Bronn, G. Bucini, K. K. Caylor, M. B. Coughenour, A. Diouf, W. Ekaya, C. J. Feral, 
E. C. February, P. G. H. Frost, P. Hiernaux, H. Hrabar, K. L. Metzger, H. H. T. Prins, S. Ringrose, W. Sea, J. Tews, J. Worden, and N. Zambatis. 2005. Determinants of woody cover in African savannas. Nature 438:846-849.

Scholes, R. J., AND S. R. ARCher. 1997. Tree-grass interactions in savannas. Annual Review of Ecology and Systematics 28:517-544.

ShapIRO, S. S., AND M. B. Wilk. 1965. An analysis of variance for normality (complete samples). Biometrika 52:591-611.

TayloR, C. A., JR., T. D. Brooks, and N. E. Garza. 1993. Effect of short duration and high-intensity, low-frequency grazing systems on forage production and composition. Journal of Range Management 46:118-121.

Teague, W. R., and S. L. Dowhower. 2003. Patch dynamics under rotational and continuous grazing management in large, heterogeneous paddocks. Journal of Arid Environments 53:211-229.

Teague, W. R., S. L. Dowhower, and J. A. Waggoner. 2004. Drought and grazing patch dynamics under different grazing management. Journal of Arid Environments 58:97-117.

Tiedemann, A. R., and J. 0. Klemmedson. 2004. Responses of desert grassland vegetation to mesquite removal and regrowth. Journal of Range Management $57: 455-465$.
Torrel, L. A., K. C. McDaniel, and K. Williams. 1992. Estimating the life of shortlived, cyclic weeds with Markov processes. Weed Technology 6:62-67.

[USDA, NRCS] US Department of Agriculture, Natural Resources Conservation Service. 2003. Ecological site information system descriptions. Available at: http://esis.sc.egov.usda.gov. Accessed 26 June 2007.

Valone, T. J., M. Meyer, J. H. Brown, and R. M. Chew. 2002. Timescale of perennial grass recovery in desertified arid grasslands following livestock removal. Conservation Biology 16:995-1002.

Van Poollen, H. W., And J. R. Lacey. 1979. Herbage response to grazing systems and stocking intensities. Journal of Range Management 32:250-253.

Ward, D., D. Saltz, and B. T. Ngairorue. 2004. Spatio-temporal rainfall variation and stock management in arid Namibia. Journal of Range Management $57: 130-140$.

Westoby, M. 1980. Elements of a theory of vegetation dynamics in the arid rangelands. Israel Journal of Botany 28:169-194.

Westoby, M., B. Walker, and I. Noy-Meir. 1989. Opportunistic management for rangelands not at equilibrium. Journal of Range Management 42:266-74.

WILM, H. G. 1945. Notes on analysis of experiments replicated in time. Biometrics $1: 16-20$. 